\title{
BAP1 Gene Mutation
}

National Cancer Institute

\section{Source}

National Cancer Institute. BAP1 Gene Mutation. NCI Thesaurus. Code C128813.

A change in the nucleotide sequence of the BAP1 gene. 